\title{
Katarzyna Szymczyk-Madej
}

Uniwersytet Ekonomiczny w Krakowie

e-mail:szymczyk@uek.krakow.pl

\section{SZABLONY KSIĘGOWE W SYSTEMIE INFORMATYCZNYM RACHUNKOWOŚCI. WYNIKI BADAŃ EKSPLORACYJNYCH}

\section{ACCOUNTING PATTERNS IN THE ACCOUNTING INFORMATION SYSTEM. RESULTS OF EXPLORATORY RESEARCH}

DOI: $10.15611 / \mathrm{pn} .2017 .471 .36$

JEL Classification: M41

\begin{abstract}
Streszczenie: Artykuł prezentuje wyniki badań przeprowadzonych w 2016 roku, dotyczące szablonów księgowych. Celem opracowania jest przedstawienie różnych aspektów związanych z funkcjonowaniem szablonów księgowych w systemie informatycznym rachunkowości (SIR), takich jak: częstotliwość wykorzystania szablonów, rodzaje operacji gospodarczych, do których są wykorzystywane, podejście pracowników do ich definiowania, kontroli itp. W pierwszej części artykułu zamieszczona została krótka charakterystyka badanych przedsiębiorstw, ich SIR oraz respondentów, którzy udzielali odpowiedzi. Zasadnicza część artykułu poświęcona została analizie wyników dotyczących szablonów księgowych. Na koniec zaprezentowano funkcjonowanie szablonów księgowych w kontekście zapisów ustawy o rachunkowości.
\end{abstract}

Słowa kluczowe: system informatyczny rachunkowości, SIR, szablon księgowy, powtarzalny zapis księgowy.

Summary: The article presents the results of the research on accounting patterns (schemes of accounting). The research was conducted in 2016. The purpose of this article is to show various aspects of a creation and functionality of accounting patterns in the accounting information system (AIS) such as the frequency of patterns' usage, the business operations which use patterns, the employee approach to their defining and controlling, etc. The first part of the article contains a brief description of the surveyed enterprises and their AIS and respondents. The main part of the article is devoted to analyzing the results of the research on accounting patterns. Finally, the functioning of accounting patterns is presented in the context of the regulations of the Accounting Act.

Keywords: accounting information system, AIS, accounting pattern, repetitive record. 


\section{Wstęp}

Odpowiednio zorganizowane i funkcjonujące systemy informacyjne wpływają na podnoszenie sprawności i skuteczności działania przedsiębiorstw. Kluczową kwestię dla skuteczności zarządzania jednostką stanowi jej środowisko informatyczne. Powszechna dostępność technologii sprawia, że trudno obecnie o jednostkę, która księgi rachunkowe prowadziłaby ręcznie [Król-Stępień 2013]. Systemy informatyczne rachunkowości (SIR) dynamicznie się więc rozwijają. W ostatnich latach można zaobserwować wzrost znaczenia możliwości odpowiedniej i elastycznej parametryzacji tych systemów związanej m.in. z masowością zapisów księgowych.

Zapisy księgowe przetwarzane w ramach SIR mają bardzo często charakter powtarzalny. Cykliczność operacji gospodarczych zależy od wielu czynników, takich jak np. rozmiar przedsiębiorstwa, specyfika jego działalności czy też częstotliwość dokonywanych transakcji zakupów i sprzedaży lub płatności bankowych. Ujęcie w księgach rachunkowych zapisów o charakterze powtarzalnym można zdecydowanie przyspieszyć, wykorzystując w tym celu odpowiednio zdefiniowane algorytmy programowe. W programach komputerowych wykorzystywanych w rachunkowości pojawiają się różne określenia takich algorytmów - mogą to być przykładowo: schematy, szablony lub wzorce księgowe. Dzięki nim następuje automatyzacja ewidencji operacji gospodarczych występujących masowo w przedsiębiorstwach. Będą to przykładowo: transakcje zakupu, sprzedaży, listy płac, amortyzacja, płatności bankowe czy też gotówkowe.

Szablony księgowe są obecnie wykorzystywane powszechnie i wpływają na jakość informacji przetwarzanej w SIR. Warto więc przyjrzeć się, jak radzą sobie z nimi pracownicy działów księgowości. Temu właśnie zagadnieniu poświęcony został niniejszy artykuł. Celem autora było zbadanie różnych aspektów związanych z funkcjonowaniem szablonów księgowych, takich jak: częstotliwość ich wykorzystania, rodzaje operacji gospodarczych, do których są wykorzystywane, stosunek pracowników do ich definiowania, kontroli itp. ${ }^{1}$.

\section{Wyniki badań}

Artykuł prezentuje część wyników badań przeprowadzonych w roku 2016 i dotyczących funkcjonowania systemu informatycznego rachunkowości. Ze względu na obszerność zebranego materiału w artykule skupiono się na prezentacji wyników opisujących wykorzystanie szablonów księgowych w przedsiębiorstwach. Jako metodę badawczą zastosowano metodę sondażową - ankietę.

Uzyskano odpowiedzi na 82 ankiety. Badania przeprowadzone zostały dwutorowo - formularze ankiet zostały rozesłane pocztą do losowo wybranej grupy

\footnotetext{
${ }^{1}$ Publikacja została dofinansowana ze środków przyznanych Wydziałowi Zarządzania Uniwersytetu Ekonomicznego w Krakowie, w ramach dotacji na utrzymanie potencjału badawczego.
} 
przedsiębiorstw oraz przekazane do przedsiębiorstw za pośrednictwem słuchaczy studiów podyplomowych kierunków Rachunkowość i Finanse oraz Rachunkowość i Podatki.

Kwestionariusz został podzielony na kilka tematycznych sekcji:

- pierwsza - formalne wprowadzenie (zawarto tu informacje odnośnie do tego, kto i w jakim celu prowadzi badanie),

- druga - dotycząca budowy i charakterystyki SIR,

- trzecia - zasadnicza, w której zebrano m.in. pytania dotyczące szablonów księgowych,

- czwarta - tzw. metryczka, mająca na celu ogólną charakterystykę badanego przedsiębiorstwa oraz respondenta.

Wyniki badań zostały zaprezentowane w postaci procentowej, którą należy interpretować jako udział odpowiedzi danego typu w ogólnej liczbie odpowiedzi uzyskanych na to pytanie. Należy także zaznaczyć, że w celu łatwiejszej interpretacji danych, przy formułowaniu wniosków często agregowano poszczególne odpowiedzi.

Wśród przedsiębiorstw, które wzięły udział w badaniach, około połowę (59\%) stanowiły przedsiębiorstwa małe (od 1 do 50 pracowników), blisko 20\% - przedsiębiorstwa średnie (od 51 do 250 pracowników), a 21\% przedsiębiorstwa duże. Zdecydowana większość przedsiębiorstw miała status jednostek prywatnych (87\%), pozostała część to jednostki państwowe, komunalne lub z sektora finansów publicznych. W badanych przedsiębiorstwach prowadzona była działalność usługowa (78\%), handlowa (32\%) i produkcyjna (26\%). Respondentami ankiety były osoby bezpośrednio związane z systemem rachunkowości przedsiębiorstw - główni księgowi i dyrektorzy finansowi $(12 \%)$ oraz inni pracownicy działu księgowości $(88 \%)$.

Liczebność personelu działu rachunkowości w badanych przedsiębiorstwach została przedstawiona w tabeli 1 . Prawie połowa (47\%) badanych przedsiębiorstw zatrudnia w tym dziale do 5 pracowników. Ponad 10 pracowników jest w jednej trzeciej badanych przedsiębiorstw (33\%), z czego przedsiębiorstwa zatrudniające powyżej 25 pracowników w dziale rachunkowości stanowią 18\%.

Tabela 1. Liczba osób zajmujących się prowadzeniem rachunkowości w badanych przedsiębiorstwach

\begin{tabular}{|l|c|}
\hline \multicolumn{1}{|c|}{ Liczba osób } & Udział [\%] \\
\hline $1-2$ & 20 \\
\hline $3-5$ & 27 \\
\hline $6-10$ & 20 \\
\hline $11-25$ & 15 \\
\hline Powyżej 25 & 18 \\
\hline
\end{tabular}

Źródło: opracowanie własne. 
Z odpowiedzi na pytania o stopień wykorzystywania przez badane przedsiębiorstwa swojego systemu informatycznego rachunkowości wynika (tab. 2), że - poza podstawowym zastosowaniem systemu do prowadzenia księgowości (w 100\% przedsiębiorstw) - jego typowe przeznaczenie to wymiana dokumentów z ZUS, przelewy bankowe (odpowiednio 91\% i 89\%), obsługa kadr i płac (odpowiednio 81\% i 90\%), zakupy i sprzedaż (odpowiednio: 54\% i 70\%) oraz zarządzanie środkami trwałymi (71\%). Są to obszary, w których SIR jest tradycyjnie wykorzystywany, dlatego ich duży udział nie jest tutaj zaskoczeniem. Wyniki te potwierdzają też inne badania (por. [Jaworski 2011; Szymczyk-Madej 2014]).

Tabela 2. Zastosowanie SIR w badanych przedsiębiorstwach

\begin{tabular}{|l|c|}
\hline \multicolumn{1}{|c|}{ Wykorzystanie systemu } & Udział [\%] \\
\hline Księgowość & 100 \\
\hline Kadry & 81 \\
\hline Płace & 90 \\
\hline Zakupy & 54 \\
\hline Sprzedaż & 70 \\
\hline Zarządzanie środkami trwałymi & 71 \\
\hline Gospodarka magazynowa & 37 \\
\hline Przelewy (płatności) bankowe & 89 \\
\hline Wymiana dokumentów z ZUS & 91 \\
\hline Analizy finansowe & 23 \\
\hline
\end{tabular}

Źródło: opracowanie własne.

Z uzyskanych danych wynika, że zdecydowana większość używanego oprogramowania to programy standardowo dostępne na rynku (prawie 90\%). Oprogramowanie takie jest powszechne w małych przedsiębiorstwach - niemal wszystkie korzystają wyłącznie z takich właśnie programów (por. [Jaworski 2011; Szymczyk-Madej 2014]). Jedynie nieliczne, przede wszystkim duże przedsiębiorstwa wykorzystują oprogramowanie napisane na zamówienie przez firmę zewnętrzną lub przez informatyków zatrudnionych w badanym przedsiębiorstwie. Wśród najczęściej wymienianych przez ankietowanych systemów wskazać należy: Comarch ERP Optima, Sage Symfonia, Insert GT, SAP ERP, ENOVA (por. [DiS 2012]).

Jednym z problemów poruszanych $\mathrm{w}$ ankiecie były zachowania respondentów związane z szablonami księgowymi. Z udzielonych odpowiedzi wynika, że szablony te są wykorzystywane w $83 \%$ przedsiębiorstw. Wśród respondentów, którzy udzielali odpowiedzi na pytania o szablony księgowe, ponad dwie trzecie $(68 \%)$ zadeklarowało ich samodzielne definiowanie lub uczestniczenie w procesie ich tworzenia (78\%).

W ankiecie zapytano też o szacunkowy procent zapisów księgowych, które są wprowadzane do ksiąg rachunkowych automatycznie za pośrednictwem szablonów 
księgowych. Znaczna część respondentów (74\%) wskazała, że w ten sposób księguje się ponad połowę dokumentów. Jedynie $6 \%$ pytanych uznało, że takich dokumentów jest mniej niż 25\%. Szczegółowy rozkład odpowiedzi zawiera tabela 3.

Tabela 3. Szacunkowy odsetek zapisów księgowych wprowadzanych do ksiąg automatycznie (z wykorzystaniem szablonów księgowych)

\begin{tabular}{|l|c|}
\hline \multicolumn{1}{|c|}{ Procent zapisów } & Udział [\%] \\
\hline Mniej niż $25 \%$ & 6 \\
\hline $25-50 \%$ & 20 \\
\hline $50-75 \%$ & 42 \\
\hline Ponad $75 \%$ & 32 \\
\hline
\end{tabular}

Źródło: opracowanie własne.

Z odpowiedzi udzielonych na pytanie o rodzaj zapisów ewidencjonowanych z wykorzystaniem szablonów księgowych wynika, że najczęściej występują one przy księgowaniu zakupów i sprzedaży materiałów, towarów i usług (odpowiednio 96\% i 92\%). Często są one wykorzystywane także do takich zapisów księgowych, jak wynagrodzenia $(73 \%)$, amortyzacja (71\%), płatności bankowe $(61 \%)$ i gotówkowe (50\%) (zob. tab. 4).

Tabela 4. Zapisy księgowe ewidencjonowane z wykorzystaniem szablonów księgowych

\begin{tabular}{|l|c|}
\hline \multicolumn{1}{|c|}{ Rodzaj zapisu } & Udział [\%] \\
\hline Zakupy materiałów, towarów, usług & 96 \\
\hline Płatności bankowe & 62 \\
\hline Zużycie materiałów & 40 \\
\hline Sprzedaż towarów, wyrobów, usług & 92 \\
\hline Amortyzacja & 71 \\
\hline Wynagrodzenia & 73 \\
\hline Płatności gotówkowe & 50 \\
\hline $\begin{array}{l}\text { Zmiany w środkach trwałych } \\
\text { (zakup, sprzedaż itp.) }\end{array}$ & 25 \\
\hline
\end{tabular}

Źródło: opracowanie własne.

W tym miejscu należy zwrócić uwagę na fakt, że w rzeczywistości tworzenie szablonów księgowych jest często procesem skomplikowanym. Wymaga ono nie tylko wiedzy z zakresu rachunkowości, ale również bardzo dobrej znajomości funkcji wykorzystywanego programu i logiki jego działania. Dobry szablon musi mieć charakter uniwersalny i często wymaga odwołań do informacji wprowadzanych w różnych miejscach programu, takich jak np. parametry konfiguracyjne, kartoteki czy plan 
kont. Jednak im bardziej uniwersalny ma być szablon i im więcej dokumentów ma być zaksięgowanych za jego pośrednictwem, tym bardziej skomplikowana jest jego definicja. Przykładowo, do zaksięgowania transakcji sprzedaży towaru, wyrobu czy usługi można utworzyć trzy oddzielne szablony (odrębnie dla każdego sprzedawanego składnika) albo skonstruować jeden szablon, w którym wykorzystana będzie funkcja warunku i różne konta przychodów, dla różnych sprzedawanych komponentów. Oczywiście to drugie rozwiązanie będzie trudniejsze, jeśli chodzi o samą definicję szablonu. Ma ono jednak jedną zasadniczą zaletę: za pomocą jednego szablonu będzie można księgować wszystkie transakcje sprzedaży bez konieczności wskazywania na liście dokumentów właściwych dla odpowiedniego szablonu księgowego. Innym przykładem może być tworzenie szablonu dla transakcji zakupu materiału od różnych kontrahentów. Oczywiście można utworzyć wiele szablonów indywidualnie dla każdego kontrahenta, jednak lepszym rozwiązaniem będzie utworzenie jednego szablonu obowiązującego wszystkich kontrahentów. Wymagać to jednak będzie odpowiedniego odwołania do kartotek kontrahentów i parametryzacji programu w zakresie automatycznego tworzenia właściwych kont analitycznych.

Tworzenie poprawnych szablonów księgowych nastręcza często dużo trudności. Kwestia ta była poruszona w ankiecie. Na pytanie o poziom trudności przy konstruowaniu szablonów księgowych większość respondentów uznała ich tworzenie za przeciętnie trudne $(60 \%)$. Proces ten jako trudny lub nawet bardzo trudny postrzega $28 \%$ pytanych. Tylko $12 \%$ oceniło to jako „łatwe"”.

W związku z trudnościami napotykanymi przy definiowaniu szablonów księgowych istotna była też odpowiedź na pytanie, kto w przedsiębiorstwie jest odpowiedzialny za ich tworzenie. Na podstawie wyników przedstawionych w tabeli 5 można stwierdzić, że zajmuje się tym przede wszystkim główny księgowy (76\% odpowiedzi „zawsze” lub „często”). Pozostali pracownicy działu księgowości robią to rzadziej (51\% odpowiedzi „zawsze” lub „często”). Osoby te rzadko są wspierane przez informatyków lub konsultantów reprezentujących producenta oprogramowania. Co oznacza, że należy podkreślić wagę szkoleń przeprowadzanych na etapie wdrożenia oprogramowania, ponieważ bez odpowiedniego poziomu wiedzy z zakresu funkcjonowania SIR tworzenie dobrych szablonów jest praktycznie niemożliwe.

Jedną z wielu zalet systemów informatycznych rachunkowości jest duża szybkość przetwarzania danych uzyskana między innymi dzięki automatyzacji procesów:

- wprowadzania danych (wykorzystanie w tym celu dokumentów elektronicznych, skanerów dokumentów, kart magnetycznych itp.),

- dekretacji powtarzalnych księgowań (np. faktur sprzedaży, zakupu, dokumentów magazynowych) na podstawie zdefiniowanych reguł (szablonów księgowych),

${ }^{2}$ Znajduje to też potwierdzenie w wieloletnich obserwacjach autorki przeprowadzonych podczas zajęć i kursów z obsługi programu Optima, wykorzystywanego m.in. do prowadzenia ksiąg rachunkowych i popularnego na rynku małych i średnich przedsiębiorstw. Większość błędów popełnianych przez studentów podczas laboratoriów i zaliczeń przedmiotu dotyczyła właśnie szablonów księgowych i zdecydowanie był to dla nich największy problem. 
Tabela 5. Osoby odpowiedzialne za definiowanie szablonów w przedsiębiorstwach

\begin{tabular}{|l|c|c|c|c|}
\hline \multicolumn{1}{|c|}{$\begin{array}{c}\text { W Państwa jednostce szablony } \\
\text { księgowe... }\end{array}$} & $\begin{array}{c}\text { zawsze } \\
\text { (tak) [\%] }\end{array}$ & $\begin{array}{c}\text { większość } \\
\text { (często) [\%] }\end{array}$ & $\begin{array}{c}\text { niektóre } \\
\text { (rzadko) [\%] }\end{array}$ & $\begin{array}{c}\text { nie } \\
\text { (nigdy) [\%] }\end{array}$ \\
\hline $\begin{array}{l}\text { definiuje główny księgowy lub inna } \\
\text { osoba nadzorująca przebieg prac } \\
\text { w dziale księgowości }\end{array}$ & 28 & 48 & 12 & 12 \\
\hline $\begin{array}{l}\text { definiują pozostali pracownicy działu } \\
\text { księgowości }\end{array}$ & 14 & 37 & 29 & 20 \\
\hline $\begin{array}{l}\text { definiują informatycy zatrudnieni } \\
\text { w jednostce }\end{array}$ & 4 & 8 & 15 & 73 \\
\hline $\begin{array}{l}\text { definiują konsultanci z firmy } \\
\text { serwisującej oprogramowanie } \\
\text { finansowo-księgowe }\end{array}$ & 9 & 11 & 24 & 56 \\
\hline
\end{tabular}

Źródło: opracowanie własne.

Tabela 6. Kontrola szablonów księgowych

\begin{tabular}{|l|c|c|c|c|}
\hline \multicolumn{1}{|c|}{ W Państwa jednostce... } & $\begin{array}{c}\text { zawsze } \\
\text { (tak) [\%] }\end{array}$ & $\begin{array}{c}\text { większość } \\
\text { (często) [\%] }\end{array}$ & $\begin{array}{c}\text { niektóre } \\
\text { (rzadko) [\%] }\end{array}$ & $\begin{array}{c}\text { nie } \\
\text { (nigdy) [\%] }\end{array}$ \\
\hline $\begin{array}{l}\text { szablony księgowe są systematycznie } \\
\text { weryfikowane }\end{array}$ & 24 & 13 & 40 & 23 \\
\hline $\begin{array}{l}\text { szablony księgowe mogą być } \\
\text { modyfikowane przez dowolnego } \\
\text { pracownika }\end{array}$ & 21 & 19 & 13 & 47 \\
\hline $\begin{array}{l}\text { szablony księgowe mają zapisaną } \\
\text { informację o osobie, która je } \\
\text { zdefiniowała }\end{array}$ & 67 & 11 & 6 & 16 \\
\hline $\begin{array}{l}\text { szablony księgowe mają zapisaną } \\
\text { informację o osobie, która je } \\
\text { zmodyfikowała }\end{array}$ & 65 & 13 & 4 & 18 \\
\hline $\begin{array}{l}\text { szablony księgowe mają zapisaną } \\
\text { informację o dacie ich utworzenia } \\
\text { i modyfikacji }\end{array}$ & 63 & 12 & 10 & 15 \\
\hline $\begin{array}{l}\text { w wykorzystywanym } \\
\text { oprogramowaniu funkcjonuje system } \\
\text { nadawania uprawnień do tworzenia } \\
\text { szablonów księgowych, dzięki } \\
\text { czemu możliwość ich tworzenia } \\
\text { i modyfikowania mają tylko wybrani } \\
\text { pracownicy }\end{array}$ & 47 & 6 & 14 & 33 \\
\hline
\end{tabular}

Źródło: opracowanie własne.

- $\quad$ sporządzania dokumentów księgowych i raportów (np. przelewy bankowe, noty odsetkowe, faktury, polecenia księgowania, sprawozdania finansowe, deklaracje podatkowe itp.), 
- kontroli (np. kontrola zgodności z zasadą podwójnego zapisu, kontrola zgodności sum bilansowych, obrotów i sald).

$\mathrm{Z}$ tą niewątpliwą zaletą wiąże się jednak poważna wada tych systemów, jaką jest utrudniona wykrywalność popełnionych błędów i zwiększenie skali ich występowania na skutek automatycznej powtarzalności operacji. Trzeba bowiem pamiętać o tym, że błąd popełniony w definicji szablonu księgowego czy też w parametrze stałym będzie występował tyle razy, ile razy dany szablon czy parametr zostaną wykorzystane. Przy częściej używanych szablonach mogą to być nawet setki czy tysiące wystąpień. Dlatego, aby zabezpieczyć się przed potencjalnymi negatywnymi skutkami tego rodzaju błędów, istotne jest niezwykle staranne definiowanie szablonów księgowych przez osoby posiadające wiedzę, umiejętności i doświadczenie na odpowiednim poziomie. Ważna jest też bieżąca kontrola szablonów księgowych zapewniająca im, w dłuższej perspektywie czasu, aktualność i odpowiednią jakość.

Dlatego też w ankiecie znalazły się pytania o sposób modyfikacji szablonów księgowych, prowadzenie ich bieżącej kontroli oraz uprawnienia do zmian szablonów. Odpowiedzi na te pytania zebrano w tabeli 6 .

Jak wynika z zestawienia w tab. 6 , systematyczna weryfikacja szablonów księgowych jest na niskim poziomie. Aż $63 \%$ respondentów stwierdziło, że weryfikuje je rzadko (40\%) albo wcale (23\%). Oznacza to, że pracownicy działów księgowości mają duże zaufanie do raz zdefiniowanych formul. $Z$ drugiej strony szablony te mogą być stosunkowo łatwo modyfikowane. Prawie połowa respondentów wskazała, że w programach nie ma kontroli (lub występuje rzadko) nadawania uprawnień użytkownikom systemu w zakresie definiowania szablonów księgowych. Ponad 1/3 respondentów (40\%) podała, że w ich systemie szablon księgowy może modyfikować dowolny pracownik (21\% odpowiedzi „zawsze”, 19\% „często”). Z czego wynika, że zaufanie do poprawności i niezmienności szablonów księgowych powinno być mocno ograniczone.

Z kolei pozytywnie należy ocenić, że szablony księgowe bardzo często mają zapisaną informację o dacie ich utworzenia (63\% „,zawsze”, $12 \%$ „większość”) i o osobie, które je zdefiniowała (67\% ,zawsze”, 11\% „większość”) i zmodyfikowała (65\% „Zawsze”, 13\% „większość”). Z pewnością poczucie odpowiedzialności za definicję szablonu lub jego modyfikację jest większe w sytuacji, gdy pracownik ma świadomość, że jego dane zostaną powiązane z szablonem. Natomiast odległa data utworzenia szablonu skłania do przemyśleń, czy nie jest konieczna jego weryfikacja, wywołana np. zmieniającymi się warunkami prawnymi czy organizacyjnymi, w których działa przedsiębiorstwo.

\section{Ustawa o rachunkowości a szablony księgowe}

System informatyczny rachunkowości powinien być tak zaprojektowany, by stosowane w nim rozwiązania i procedury były zgodne z zasadami rachunkowości, pomagały jak najlepiej spełniać wymagania ustawowe stawiane księgom rachunkowym i jednocześnie usprawniały zarządzanie przedsiębiorstwem [Król-Stępień 2013]. 
W ustawie o rachunkowości (UoR) brak jest szczegółowych wytycznych dotyczących konstruowania i wykorzystania szablonów księgowych. Część zapisów ustawowych jest jednak powiązana z tym problemem, dlatego poddano je tutaj bliższej analizie.

W art. 20 ust. 5 UoR czytamy, że „przy prowadzeniu ksiąg rachunkowych przy użyciu komputera za równoważne z dowodami źródłowymi uważa się zapisy w księgach rachunkowych wprowadzone automatycznie za pośrednictwem urządzeń łączności, informatycznych nośników danych lub tworzone według algorytmu (programu) na podstawie informacji zawartych już w księgach". Jednak ustawodawca stawia tu pewne warunki, które muszą być spełnione podczas rejestrowania tych zapisów:

„1. uzyskają one trwale czytelną postać zgodną z treścią odpowiednich dowodów księgowych,

2. możliwe jest stwierdzenie źródła ich pochodzenia oraz ustalenie osoby odpowiedzialnej za ich wprowadzenie,

3. stosowana procedura zapewnia sprawdzenie poprawności przetworzenia danych oraz kompletności i identyczności zapisów,

4. dane źródłowe w miejscu ich powstania są odpowiednio chronione, w sposób zapewniający ich niezmienność, przez okres wymagany do przechowywania danego rodzaju dowodów księgowych".

Ze względu na te wytyczne w ankiecie poruszono też istotną kwestię odpowiedniego oznaczenia i dalszego postępowania z zapisami księgowymi powstającymi w oparciu o szablony księgowe. Odpowiedzi na te pytania przedstawiono powyżej (tab. 6).

W związku z takim stanowiskiem ustawodawcy można tu zadać pytania:

1. Czy w przedsiębiorstwach, w których szablony księgowe nie są oznaczone co do osoby, która je utworzyła lub zmodyfikowała, spełniony jest warunek ustawowy postawiony w pkt 2 ?

2. Czy w przedsiębiorstwach, w których szablony mogą modyfikować dowolne osoby i nie ma systemu nadawania uprawień w tym zakresie tylko wybranym pracownikom, dane te są odpowiednio chronione?

3. Czy jeśli nie ma bieżącej weryfikacji szablonów, stosowana jest odpowiednia procedura przetwarzania danych?

Zdaniem autorki tego artykułu - można mieć uzasadnioną wątpliwość co do spełnienia wymogów ustawy.

W art. 14 ust 4 UoR znajduje się zapis, że „przy prowadzeniu ksiąg rachunkowych przy użyciu komputera zapis księgowy powinien posiadać [...] dane pozwalające na ustalenie osoby odpowiedzialnej za treść zapisu". Pojawia się tu zasadnicze pytanie: kto realnie decyduje o kształcie zapisu księgowego? Osoba, która wydała tylko ostateczną dyspozycję ewidencji dokumentu, korzystając przy tym z wcześniej zdefiniowanego szablonu księgowego, czy też autor tego szablonu? Dlatego w ankiecie zamieszczono pytanie o to, czy szablony mają zapisaną informację o tym, kto je zdefiniował lub zmodyfikował, i tu odpowiedzi były w przeważającej liczbie 
przypadków twierdzące. Istotne jest jednak jeszcze, aby zapis księgowy był oznaczony co do wykorzystywanego, przy jego ewidencji, szablonu. Inaczej nie ma możliwości powiązania autora szablonu z zapisem księgowym. Tutaj również znaczna część respondentów odpowiedziała twierdząco ( $41 \%$,zawsze” i $24 \%$ „często”). Z drugiej strony trzeba jednak zwrócić uwagę na fakt, że prawie jedna czwarta przedsiębiorstw nie przechowuje wcale, lub też robi to rzadko, informacji o autorach szablonów księgowych, a w $1 / 3$ przedsiębiorstw brak jest danych o wykorzystanym szablonie przy zapisie księgowym.

Warto też zwrócić uwagę na zapis art. 24 ust. 4 pkt 3. Stwierdza on, że „księgi rachunkowe uznaje się za sprawdzalne, jeżeli zapewniona jest kontrola kompletności zbiorów systemu rachunkowości oraz parametrów przetwarzania danych".

Czy można uznać, że jest zapewniona kontrola parametrów przetwarzania danych, jeśli nie weryfikuje się szablonów księgowych, a modyfikować je mogą dowolne osoby, które mają dostęp do systemu?

Tabela 7. Oznaczenie zapisów księgowych

\begin{tabular}{|l|c|c|c|c|}
\hline \multicolumn{1}{|c|}{ W Państwa jednostce... } & $\begin{array}{c}\text { zawsze } \\
\text { (tak) [\%] }\end{array}$ & $\begin{array}{c}\text { większość } \\
\text { (często) [\%] }\end{array}$ & $\begin{array}{c}\text { niektóre } \\
\text { (rzadko) [\%] }\end{array}$ & $\begin{array}{c}\text { nie } \\
\text { (nigdy) [\%] }\end{array}$ \\
\hline $\begin{array}{l}\text { wraz z zapisem księgowym } \\
\text { zapisywana jest informacja } \\
\text { o szablonie wykorzystanym do jego } \\
\text { ewidencji }\end{array}$ & 41 & 24 & 7 & 28 \\
\hline $\begin{array}{l}\text { zapis księgowy ewidencjonowany } \\
\begin{array}{l}\text { Z wykorzystaniem szablonu } \\
\text { księgowań może być później } \\
\text { modyfikowany (jest tymczasowo } \\
\text { wprowadzany do bufora) }\end{array}\end{array}$ & & & & \\
\hline $\begin{array}{l}\text { zapis księgowy ewidencjonowany } \\
\text { z wykorzystaniem szablonu } \\
\text { księgowań nie może być później } \\
\text { modyfikowany, a jedyną możliwością } \\
\text { korekty takiego zapisu jest storno } \\
\text { księgowe }\end{array}$ & 68 & 12 & 10 & 10 \\
\hline
\end{tabular}

Źródło: opracowanie własne.

Z zastosowaniem szablonów księgowych może się także wiązać poważny problem wystąpienia błędów w zapisach księgowych, tzn. źle napisany szablon wywoła błąd $\mathrm{w}$ dokumentach, które będą księgowane z jego użyciem. Jednak jeśli błędnie zaksięgowany dokument zostanie znaleziony, ważne jest, żeby można było zidentyfikować źródło błędu. Nie jest jednak możliwe (przynajmniej w krótkim czasie) znalezienie błędu w szablonie księgowym, jeśli zapis księgowy nie jest w żaden sposób oznaczony co do szablonu, którego przy nim użyto. Niestety ponad $1 / 3$ respondentów wskazała, że zapisy księgowe nie mają lub mają rzadko przechowaną informację o szablonie księgowym. 
Sytuację tę poprawia trochę fakt, że zaufanie księgowych do szablonów jest jednak ograniczone, na co wskazują odpowiedzi na pytanie o formę zapisu księgowego utworzonego w oparciu o szablon księgowy. Zdecydowana większość respondentów wskazała odpowiedź, że zapisy są wprowadzane tymczasowo do bufora (68\% odpowiedzi „,zawsze”, 12\% „większość”). Niestety nie jest znana odpowiedź na pytanie, czy rzeczywiście zapisy te są potem jeszcze weryfikowane przed trwałym ich ujęciem w księgach, czy też jest to tylko pośredni etap księgowania.

Księgi rachunkowe powinny być prowadzone zgodnie z ustawą o rachunkowości niezależnie od techniki. Zapisy rozdziału 2 ustawy o rachunkowości dotyczącego zasad prowadzenia ksiąg można odczytać w taki sposób, że odnoszą się one raczej do ręcznego prowadzenia ksiąg rachunkowych. Takie sformułowania ustawowe mogą stwarzać wrażenie, że prowadzenie ksiąg z wykorzystaniem technologii informatycznej występuje incydentalnie. Tymczasem powszechna dostępność technologii sprawia, że trudno dziś o jednostkę, która prowadziłaby księgi ręcznie.

Ustawa o rachunkowości w sposób ogólny określa zasady prowadzenia ksiąg z wykorzystaniem systemów informatycznych, a jej przepisy nie zawierają gotowych rozwiązań. Zapisy pojawiające się w niej często mają charakter ogólny, nie nadążają za zmianami technologicznymi i nie odzwierciedlają faktycznych problemów funkcjonowania systemu rachunkowości w przedsiębiorstwie. Tym samym należałoby się zastanowić nad ponowną nowelizacją zapisów UoR w zakresie wykorzystania systemów informatycznych do prowadzenia ksiąg rachunkowych podmiotów gospodarczych (por. [Kunz, Tymińska 2014; Król-Stępień 2013]).

\section{Zakończenie}

W chwili obecnej najważniejszym narzędziem wspomagającym rachunkowość jest odpowiednie oprogramowanie komputerowe. Jego właściwe funkcjonowanie w istotny sposób rzutuje na jakość przetwarzanej informacji. SIR dynamicznie się rozwijają i stwarzają ciągle nowe możliwości prowadzenia rachunkowości.

Szablony księgowe to szansa na znaczące podniesienie efektywności pracy działu księgowości, ale też potencjalne zagrożenie dla poprawności zapisów księgowych. Niezwykle ważne jest więc, aby w przedsiębiorstwach stosowano odpowiednie procedury dotyczące staranności ich definiowania, oznaczania i kontrolowania. Jest to również zadanie dla producentów oprogramowania finansowo-księgowego, którzy powinni zadbać o możliwość tworzenia szablonów jak najbardziej uniwersalnych w jak najprostszy sposób. Ważne jest też, aby programy te miały zaprojektowane odpowiednie mechanizmy kontrolujące poprawność tworzonych szablonów. 


\section{Literatura}

Jaworski J., 2011, Organizacja i funkcjonowanie systemów ewidencyjno-rachunkowych w matych przedsiębiorstwach w Polsce. Wyniki badań, Prace Naukowe Wyższej Szkoły Bankowej w Gdańsku, tom 12, Działanie współczesnych przedsiębiorstw. Determinanty kulturowe, zasobowe i samorzadowe, red. T. Falencikowski, Warszawa.

DiS raport, 2012, Oprogramowanie dla małych i średnich przedsiębiorstw, http://www.comarch.pl/erp/ aktualnosci/ogolne/comarch-liderem-rynku-oprogramowania-dla-msp (23.08.2016).

Kunz B., Tymińska A. 2014, System informatyczny rachunkowości i jego rola w świetle ustawy o rachunkowości, Nauki o Finansach, nr 3(20), Wyd. Uniwersytetu Ekonomicznego, Wrocław.

Król-Stępień M., 2013, System informatyczny rachunkowości jako narzędzie wspomagające zarządzanie jednostka gospodarcza - wymogi ustawowe a ich praktyczne stosowanie, Zeszyty Naukowe Uniwersytetu Szczecińskiego, nr 757, Szczecin.

Szymczyk-Madej K., 2014, Budowa i funkcjonowanie systemów informatycznych rachunkowości porównanie wyników badań z lat 2005 i 2014, Prace Naukowe Uniwersytetu Ekonomicznego we Wrocławiu, nr 344, Wrocław.

Ustawa z dnia 29 września 1994 r. o rachunkowości, Dz.U. 1994, nr 121, poz. 591 z późn. zm. 